\title{
Dermoid cyst with no intracranial extension: A case report and literature review
}

Asra Tanwir

Aga Khan University

Noor Malik

Aga Khan University, noor.malik@aku.edu

Gohar Javed

Aga Khan University, gohar.javed@aku.edu

Romana Idress

Aga Khan University, romana.idress@aku.edu

Follow this and additional works at: https://ecommons.aku.edu/pakistan_fhs_mc_surg_neurosurg

Part of the Neurology Commons, Neurosurgery Commons, Pathology Commons, and the Surgery

Commons

\section{Recommended Citation}

Tanwir, A., Malik, N., Javed, G., Idress, R. (2019). Dermoid cyst with no intracranial extension: A case report and literature review. Surgical Neurology International, 10, 25.

Available at: https://ecommons.aku.edu/pakistan_fhs_mc_surg_neurosurg/189 


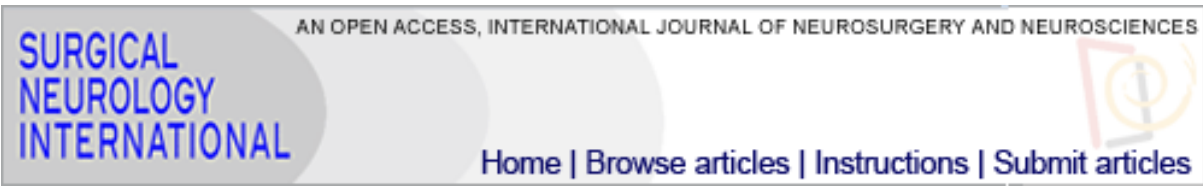

Surg Neurol Int. 2019; 10: 25.

PMCID: PMC6416756

Published online 2019 Feb 28.

PMID: $\underline{31123632}$

doi: 10.4103/sni.sni_246_18: 10.4103/sni.sni_246_18

\section{Dermoid cyst with no intracranial extension: A case report and literature review}

Asra Tanwir, ${ }^{*}$ Noor Malik, Gohar Javed, and $\underline{\text { Romana Idrees }}^{1}$

Department of Neurosurgery, Aga Khan University Hospital, Karachi, Pakistan

${ }^{1}$ Department of Pathology, Aga Khan University Hospital, Karachi, Pakistan

Asra Tanwir: asratanwir2991@hotmail.com; Noor Malik: noor.malik@aku.com; Gohar Javed:

gohar.javed@aku.com; Romana Idrees: romana.idress@aku.com

*Corresponding author

Received 2018 Jul 17; Accepted 2018 Nov 19.

Copyright : @ 2019 Surgical Neurology International

This is an open access journal, and articles are distributed under the terms of the Creative Commons AttributionNonCommercial-ShareAlike 4.0 License, which allows others to remix, tweak, and build upon the work noncommercially, as long as appropriate credit is given and the new creations are licensed under the identical terms.

\section{Abstract}

\section{Background:}

Dermoid cysts are cystic inclusion tumors. They comprise hair follicles, sweat glands, and sebaceous glands. They have lining of stratified squamous epithelium. The most common areas involved are face, lower back, and ovaries. Congenital cystic dermoid involving the anterior fontanelle with no intracranial extension is a rare scalp swelling. We present a case of dermoid cyst with no intracranial extension.

\section{Case Description:}

We report a case of 4-month-old child presented with a history of a scalp swelling since birth. The swelling increased in size progressively. Magnetic resonance imaging of the brain revealed extracranial cystic lesion over anterior fontanelle with no intracranial extension. Cyst was excised completely with no postoperative complications. On histopathology it was dermoid cyst.

\section{Conclusion:}

To the best of our knowledge, congenital dermoid cyst of the anterior fontanelles is rare. Complete surgical excision is the treatment of choice.

Keywords: Anterior fontanelle, cyst, dermoid, scalp

\section{INTRODUCTION}


Dermoid cyst is a benign, slowly growing lesion that accounts for $0.1-0.5 \%$ of all intracranial lesions.[2,, 8$]$ During the formation of the neural tube, dermoid cyst is thought to be formed from defects in the separation of neuroectoderm, resulting in sequestration of ectodermal remnants.[1] Dermoid cyst consists of semi-solid inspissated yellow material that comprises stratified squamous epithelial lining, hair and most commonly have sebaceous glands; rare presence of sweat gland is also reported in the literature. The presence of skin adnexa-like hair follicles and glands in the cyst and other contents differentiates dermoid cyst from epidermoid cyst.[3,11] Very rarely, congenital dermoid cysts over the anterior fontanelles without intracranial extension are reported.[요, 10$]$ The present paper reports a case of congenital cystic scalp swelling that was excised completely.

\section{CASE HISTORY}

A 4-month old girl was brought by her parents with complain of scalp swelling over anterior Fontanelle since birth. The swelling gradually increased in size. On examination, there was a soft, fluid-filled lesion over the anterior fontanelle, which was nontender and nonpulsatile. Trans illumination test and cough impulse were negative. There was no bruit over the swelling. Magnetic resonance imaging of brain was carried out, which revealed presence of a well-defined cystic swelling in the midline over the anterior fontanelle, measuring approximately $35 \times 30 \times 18 \mathrm{~mm}$ in transverse, anterior-posterior, and craniocaudal dimensions. It was cystic in appearance, with hyperintense signals on T2-weighted sequence, with no flow voids [ㅍigure 1a] and hypointense signals on T1-weighted sequences [iigure 1b] showing no surrounding edema on fluid-attenuated inversion recovery (FLAIR) image [ Figure 1c]. There was no contrast enhancement [Figure 1d]. This lesion was showing no diffusion restriction and no signal susceptibility on susceptibility weighted imaging sequence. The patient underwent complete surgical excision of the scalp lesion under general anesthesia. Intraoperatively, a soft, cystic, fluid filled lesion over anterior fontanelle, which was densely adherent to underlying tissue. Lesion was excised completely with no complications. Patient was discharged in stable state. Histopathology showed a cystic lesion, white in color measuring approximately $3.5 \times 2.5 \mathrm{~cm}$. It was lined by typical squamous epithelium filled with clear fluid and white keratinaceous material [Figure $\underline{2 \mathrm{a}}$ and $\underline{\mathrm{b}}$ ].

No immature components such as hair or teeth were found within the lesion. Features were consistent with dermoid cyst.

\section{DISCUSSION}

Congenital inclusion dermoid cysts are thought to arise during the third and fifth week of embryogenesis from displacement of germ cells.[] ] The initial position of ectodermal inclusion within the underlying mesoderm corresponds to the varied arrangement of craniofacial dermoid cysts.[] The incidence rates of scalp dermoid cysts range from 15 to $22 \%$.[2] The most commonly involved sites are nasal involving rhenian, periorbital involving zygomaticofrontal suture, intraoral involving floor of mouth, and post auricular.[7] In our case, lesion was involving scalp over anterior fontanelle, with no intracranial extension. Patient with dermoid cyst presents with a lesion usually at birth that can be soft, nontender or inflamed, increasing in size, and changes color frequently.[3] Dermoid cyst can remain stable for years but sometimes they become symptomatic. Rupture of dermoid cyst occurs spontaneously and in only small percentage, it can present with neurological symptoms before rupture.[토시 Cranial bone expansion and erosion are rarely seen; however, there is a possibility that they might expand cranial bones laterally. $[9, \underline{8}]$ High-risk cases need clinical and radiological features identification.[11] Computed tomography of brain is used for confirmation of lesion.[6] Complete surgical resection of lesion is the treatment of choice. However, keeping in check the risk of structure underneath lesion must be weighed against complete resection as post resection occipital neuropathy should be considered as a complication.[12] In a child with open anterior fontanelle and proximity of the cyst to the sagittal suture, the capacity to extend 
intracranially or intradurally is high. Although recurrence after complete resection is rare, close follow-up is highly recommended. In the four reported cases of recurrence in the literature, times to presentation after initial resection were 5, 12, 13, and 66 months.[4]

On histopathological examination, dermoid cyst consists of keratinizing stratified squamous epithelial lining, with some adnexal appendage structure-like intraluminal keratin and most commonly sebaceous

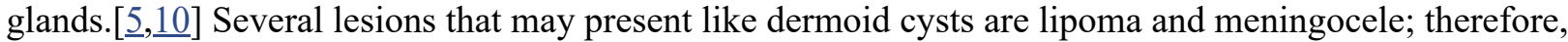
histological diagnosis is needed to differentiate scalp swellings.[]]

Imaging is important postoperatively to monitor the status of these patients. In our patient no recurrence has been noticed after 6 weeks of surgery.

\section{Declaration of patient consent}

The authors certify that they have obtained all appropriate patient consent forms. In the form the patient(s) has/have given his/her/their consent for his/her/their images and other clinical information to be reported in the journal. The patients understand that their names and initials will not be published and due efforts will be made to conceal their identity, but anonymity cannot be guaranteed.

\section{Financial support and sponsorship}

Nil.

\section{Conflicts of interest}

There are no conflicts of interest.

\section{Footnotes}

http://surgicalneurologyint.com/Dermoid-cyst-with-no-intracranial-extension:-A-case-report-and-literature-review/

\section{REFERENCES}

1. Agrawal A, Santhi V, Reddy V. Subgaleal dermoid cyst of the anterior fontanelle in a child. Egypt J Radiol Nucl Med. 2015;46:1171-4.

2. Crawford R. Dermoid cyst of the scalp: Intracranial extension. J Pediatr Surg. 1990;25:294-5. [PubMed: 2313495]

3. De Carvalho GT, Fagundes-Pereyra WJ, Marques JA, Dantas FL, de Sousa AA. Congenital inclusion cysts of the anterior fontanelle. Surg Neurol. 2001;56:400-5. [PubMed: 11755980]

4. Iwamuro Y, Shirahata M, Jito J, Tokime T, Hosotani K, Tokuriku Y. A case report of a scalp dermoid cyst containing watery-clear fluid. No Shinkei Geka. 2002;30:211-4. [PubMed: 11857947]

5. Kumar S, Singh M, Agarwal P. Giant congenital dermoid cyst of scalp. J Cran Max Dis. 2014;3:147-9.

6. Lebkowski WJ, Lebkowska U, Dzieciol J. The giant dermoid cyst of the scalp mimicking skull tumor. Case report. Rocz Akad Med Bialymst. 2000;45:47-53. [PubMed: 11712439]

7. Liu JK, Gottfried ON, Salzman KL, Schmidt RH, Couldwell WT. Ruptured intracranial dermoid cysts: Clinical, radiographic, and surgical features. Neurosurgery. 2008;62:377-84. [PubMed: 18382315]

8. Makhija D, Sisodiya N, Shah H, Waghmare M. Cystic congenital scalp inclusion dermoid: A case report. Dev Period Med. 2016;20:287-8. [PubMed: 28216482]

9. Reissis D, Pfaff MJ, Patel A, Steinbacher DM. Craniofacial dermoid cysts: Histological analysis and inter-site comparison. Yale J Biol Med. 2014;87:349-57. [PMCID: PMC4144289] [PubMed: 25191150] 
10. Stendel R1, Pietilä TA, Lehmann K, Kurth R, Suess O, Brock M. Ruptured intracranial dermoid cysts. Surg Neurol. 2002;57:391-8. [PubMed: 12176198]

11. Wax MK, Briant TD. Epidermoid cysts of the cranial bones. Head Neck. 1992;14:293-6. [PubMed: 1517079]

12. Yang JS, Choi HJ, Cho YJ, Kang SH. Sensory complications in patients after scalp mass excision and its anatomical considerations. J Korean Neurosurg Soc. 2014;55:200-4. [PMCID: PMC4094744]

[PubMed: 25024823]

\section{Figures and Tables}




\section{Figure 1}
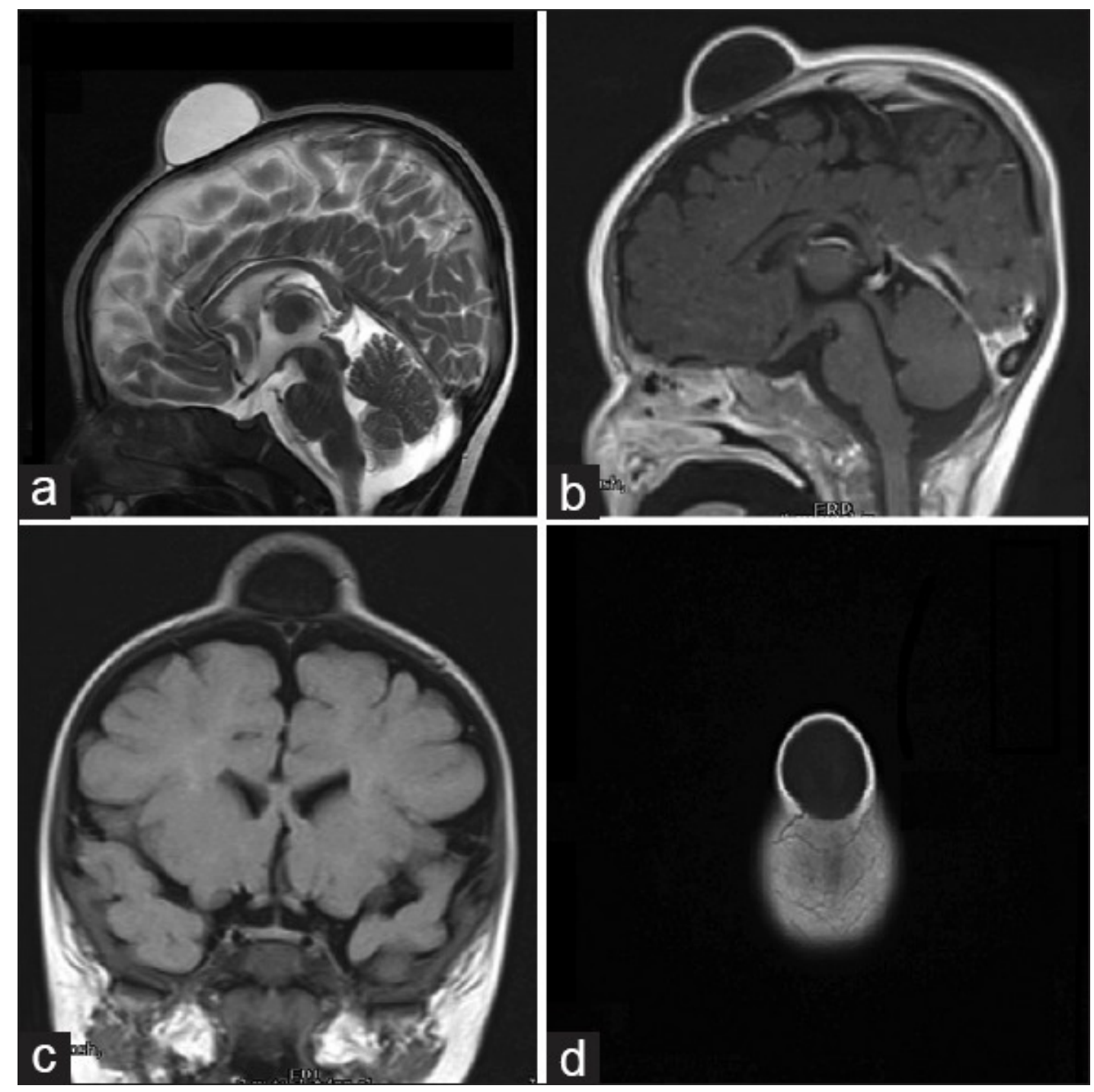

Open in a separate window

(a) T2-weighted image (sagittal section) showing the cystic swelling. (b) T1-weighted image with contrast showing no contrast enhancement. (c) FLAIR (coronal section) showing the presence of cystic swelling. (d) T1 (axial) showing cystic lesion on vertex 


\section{Figure 2}

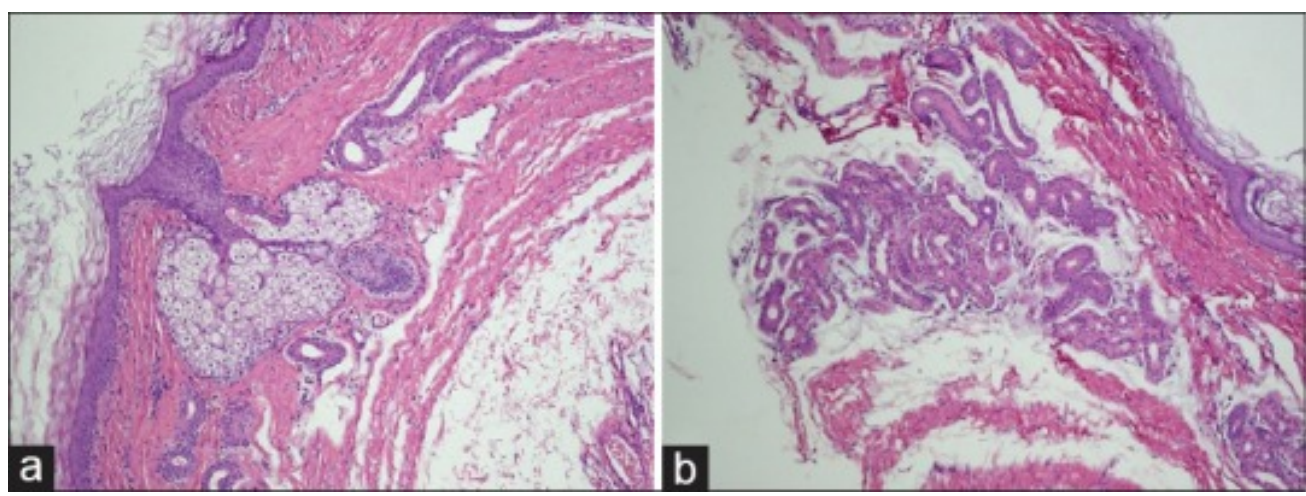

(a) Low-power magnification showing squamous epithelium, adnexa, and sebaceous glands. (b) High-power magnification showing skin and adnexa

Articles from Surgical Neurology International are provided here courtesy of Wolters Kluwer -- Medknow Publications 